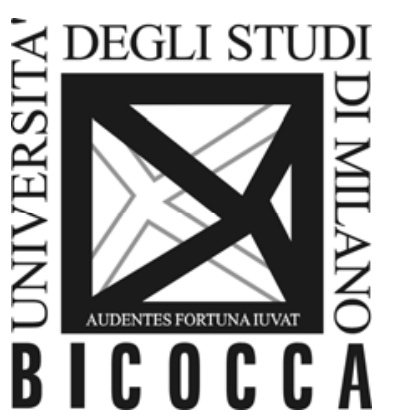

DEPARTMENT OF ECONOMICS,
MANAGEMENT AND STATISTICS
UNIVERSITY OF MILAN - BICOCCA

DEMS WORKING PAPER SERIES

\title{
The cost of defaults: the impact of haircuts on economic growth
}

Silvia Marchesi, Valeria Prato

No. 265 - December 2013

Dipartimento di Economia, Metodi Quantitativi e Strategie di Impresa Università degli Studi di Milano - Bicocca 


\title{
The cost of defaults: the impact of haircuts on economic growth
}

\author{
Silvia Marchesi and Valeria Prato \\ Università di Milano Bicocca and Centro Luca d'Agliano*
}

December 2013

\begin{abstract}
This paper studies the impact of debt default on economic growth taking into account the depth of a debt restructuring. More specifically, creditors' losses (or haircuts) are used as proxies of the severity of the default episoded. Analyzing 89 defaults in 72 countries over the period 1979-2005, consistently with previous results in this literature, we find that defaults have a negative and significant impact on short-term output growth. Moreover, controlling for the severity of the default through the haircut's size, we find that the severity of the default is indeed correlated with a further contraction in output one year after the default and with a positive increase in output three years after the default. Therefore, the use of a variable which is taken as a proxy of the severity of the default episode allows us to detect a more lasting (and eventually positive) effect of debt default on growth.
\end{abstract}

Keywords: Haircuts, Output losses, Sovereign defaults

JEL Classification: F34, G15, H63,

\footnotetext{
${ }^{*}$ Corresponding author: Silvia Marchesi, Dipartimento di Economia Politica, Piazza Ateneo Nuovo 1, I-20126 Milano. Tel. +39 02 64483057; Fax. +39 02 64483085; E-mail: silvia.marchesi@unimib.it.
} 


\section{Introduction}

Sovereign debt problems and debt restructuring have traditionally been very much topical for emerging economies in light of the debt crisis of the early 1980s and 1990s. After the recent European sovereign debt crisis, however, debt problems became important for developed economies as well (e.g., Zettelmeyer et al. 2013). Sovereign defaults and debt restructurings are not costless as a sovereign's unilateral decision to stop servicing its debt implies important economic costs. At least this is what the sovereign debt literature has assumed as a government's main incentive to honor its debt obligations. ${ }^{1}$

The (empirical) literature analyzing the impact of sovereign defaults has tested the impact of default mainly looking at international trade, GDP growth and international credit market. There is evidence documenting trade cost of defaults in particular for export-oriented industries (Rose 2005, Borensztein and Panizza 2010). ${ }^{2}$ As the direct effect of default on growth is concerned, a strong but short-lived negative contemporaneous effect on growth is found by Sturzenegger (2004) and later confirmed by Borensztein and Panizza (2009) and De Paoli et al. (2006) and (2009). ${ }^{3}$ Using higher frequency data, Levy Yeyati and Panizza (2011) actually show that output contraction precedes default and that default episodes seem actually already to mark the beginning of the economic recovery. ${ }^{4}$ Finally, gaining access to capital markets after a default seems to be more affected by the general conditions of the capital markets than by discrimination against former defaulters (e.g., Lindert and Morton 1989, English 1996, Gelos et al. 2004). Apparently the access to credit market is influenced by more recent repayments but not by distant repayment history (e.g., Ozler, 1993), which is also confirmed in more recent papers documenting a short-lived effect of default on spreads and market access (e.g., Borensztein and Panizza, 2009, and Panizza et al. 2009).

Only very recently, Cruces and Trebesch (2013a) came to different conclusions, which are more in line with the effects of a default according to the theory. More specifically, by including in their analysis a measure of investors' losses (or "haircuts"), they show that restructuring involving higher haircuts are associated with significantly higher subsequent

\footnotetext{
${ }^{1}$ There are two main mechanisms by which foreign creditors can enforce repayment, at least to a certain level. They consist of a direct punishment, either direct sanctions (mainly trade sanctions) or just preventing a country form fully enjoying its gains from trade, and excluding it from the access to international capital market in the future, the so called "reputational incentive" (e.g., Eaton and Gersovitz 1981, Cole et al. 1995, Wright 2002).

${ }^{2}$ While Rose (2005) found that official debt default is associated with a long-lasting decline in bilateral trade, Borensztein and Panizza (2010) find that export-oriented industries tend to suffer in the aftermath of a default, but only as a transitory effect.

${ }^{3}$ Furceri and Zdzienicka (2012) also find long-lasting output losses after debt crises. While the original theoretical literature on sovereign debt found that defaults tend to happen during good times, more recent theoretical work is consistent with the empirical evidence showing that defaults tend to happen during recessions (e.g., Tomz and Wright 2007).

${ }^{4}$ In all these cases, however, the costs specifically associated with a default (on the top of those related to the crisis itself) are quite difficult to identify. Therefore, while there is evidence that sovereign debt defaults are negatively correlated with economic growth, there is no study finding a causal relationship going from default to growth.
} 
bond yield spreads and longer periods of capital market exclusion (that is credit markets do not seem to "forgive and forget," as in Bulow and Rogoff 1989). ${ }^{5}$ Such different result with respect to the previous literature is remarkable and it is attributed to a more precise measurement of a country's repayment record. Therefore, their analysis does suggest that it is crucial to consider the magnitude of past defaults and not only the default event per se.

In this paper we apply a similar methodology to Cruces and Trebesch's (2013a) to the analysis of the impact of a debt default on economic growth. Specifically, we take the creditors' losses (the so called haircuts) as proxy of the severity of the default episode and we verify if more severe haircuts have a stronger impact on (annual) economic growth. While the overall evidence indicates that default episodes are negatively correlated with growth, in this literature the decision of a default has been modelled as a binary decision, in which any missed payment becomes an explanatory variable for past credit history but ignores the large variation in restructuring outcomes. This circumstance implies, de facto, no distinction between the different degrees of severity of the default episodes and could (at least partially) explain why previous literature has so far detected negligible medium-run effects of debt defaults on growth. To the best of our knowledge this is the first time that such distinction is taken into account investigating the effects of defaults on economic growth.

Analyzing 89 defaults in 72 countries over the period 1979-2005, we find that defaults have a negative and significant impact on short-term output growth, consistently with previous results in this literature. However, controlling for the severity of the default through the haircut's size, we find that the severity of the default is indeed correlated with a further contraction in output one year after the default and with a positive increase in output three years after the default episode. Therefore, the use of a variable taken as a proxy of the severity of the default allows us to detect a more lasting (and eventually positive) effect of a debt default on growth.

The rest of this paper is organized as follows. Section 2 describes the empirical model and the data while the results are presented in Section 3. Finally, Section 4 summarizes and concludes.

\section{Empirical model}

In this section, we analyze the effects of a debt default on economic growth by controlling for the severity of the default episode. For this reason we include a measure of the creditors' losses (the so called haircuts) as a proxy of the severity of the default episode and we want to verify if more severe haircuts have a stronger impact on (annual) growth.

\footnotetext{
${ }^{5}$ Bulow and Rogoff (1989) question the belief that reputational considerations (more specifically the exclusion from world capital markets) would induce a country to repay its debt. Their argument is that cutting off access to borrowing alone cannot enforce repayment if lending (that is the ability to write cash-in-advance insurance contracts in international markets) is still allowed.
} 


\subsection{Data on haircuts and defaults}

The data on haircuts and defaults come from the database built by Benjamin and Wright (2009), which is in turn drawn from a variety of sources. ${ }^{6}$ The database covers 90 defaults episodes by 73 countries focusing on defaults of sovereign debts owed to private creditors (banks and bondholders). ${ }^{7}$ Benjamin and Wright (2009) base their measures of haircuts on the World Bank's estimates of debt stock reduction, interest and principal forgiven, and debt buybacks, as published in the Global Development Finance (GDF). Specifically, they combine the World Bank's estimates of the reduction in the face value of the debt with estimates of the forgiveness of arrears on interest and principal. As the World Bank data do not make any distinction between debt forgiveness by private creditors and official creditors, they scale the amount of forgiveness using estimates of the total amount of debt renegotiated, and based on the proportion owed to private creditors taken from both GDF and Institute for International Finance. ${ }^{8}$

The resulting series on private creditor haircuts covers 90 defaults and renegotiations by 73 developing countries that were completed after GDF data on debt forgiveness first became available in 1989 and that ended prior to 2006. Appendix C presents the data on default and haircut while Figure 1 shows the distribution of haircuts.

\section{INSERT FIGURE 1}

Figure 1 show that the haircut takes the value zero in 13 default episodes in our sample. The majority of the haircuts lies in the interval 31-70\% (more specifically in both the intervals $41-50 \%$ and $61-70 \%$ ). The average haircut value is about $37 \%$, while the median value is $42 \% .^{9}$

\subsection{Method}

We examine the impact of default on growth over the 1978-2008 period. We obtain an unbalanced panel which comprises a maximum of 72 developing countries, depending on the control variables we include. We adopt a OLS fixed effects estimator in order

\footnotetext{
${ }^{6}$ Benjamin and Wright (2009) built a new database covering 90 recent sovereign defaults showing that, not only default negotiations take a long time to complete, but also that they are ineffective in repaying creditors and reducing the debtors' burden. Moreover, the greater the contraction in output in the year of the default, the greater the haircut and the length of the default.

${ }^{7}$ Their definition of sovereign debt includes debts owed either directly by a country's national government, or owed indirectly by virtue of a government guarantee. The source of their data is Standard and Poors (see Beers and Chambers 2006).

${ }^{8}$ Losses in different years were added together and discounted back to the time of the default using a ten percent discount rate. Benjamin and Wright (2009), in appendix C of their paper, shows that their estimates correlate closely with those of other studies (like for example Cline 1995, and Sturzenegger and Zettelmeyer 2008).

${ }^{9}$ For more details see Benjamin and Wright (2009).
} 
to control for country unobservables and to correct for heteroskedasticity. The results are qualitatively unchanged when we correct for cross-sectional heteroskedasticity across countries and autocorrelation within panels, we do not lag the explanatory variables, or we omit year dummies.

Specifically we test

$$
\begin{aligned}
y_{i t}= & \alpha+\beta X_{i t}+\gamma H_{i t-1}+\gamma_{1} H_{i t}+\gamma_{2} H_{i t+1}+\gamma_{3} H_{i t+2}+\gamma_{4} H_{i t+3}+ \\
& \delta D_{i t-1}+\delta_{1} D_{i t}+\delta_{2} D_{i t+1}+\delta_{3} D_{i t+2}+\delta_{4} D_{i t+3}+\eta_{i}+\tau_{t}+u_{i t},
\end{aligned}
$$

where $y_{i t}$ represents per capita growth in country $i$ at period $t, H_{i t}$ is the haircut associated to the default of the year $t$ in country $i, D_{i t}$ is a binary variable equal to one in case of a default of country $i$ in the year $t$, and $X$ is a vector containing our control variables. Following the way in which the haircut variable has been built by the two authors, the haircut takes its own value only when the (binary) variable denoting default is equal to one, being equal to zero otherwise. We have then generated four more dummies which are equal to one the year before the default $\left(D_{i t-1}\right)$, and the three following years after the default episode (i.e., $D_{i t+1}, D_{i t+2}$ and $D_{i t+3}$ ). Following Cruces and Trebesch (2013a) we used the same procedure for the haircut. We then generated four more variables denoting the haircut at $t-1\left(H_{i t-1}\right)$ and at the three following years after the default episode (i.e., $H_{i t+1}, H_{i t+2}$, and $H_{i t+3}$ ). Finally, $\eta_{i}$ and $\tau_{t}$ denote country and time dummies, respectively, which allow us to control for both countries unobservables and common macroeconomic factors.

Our choice of control variables follows the literature on the impact of default on output growth such as Levy Yeyati and Panizza (2011) and the empirical literature on the determinants of growth (see, for example, Barro and Sala-i-Martin 2004). Our selection then includes economic, institutional, and social variables. More specifically, we control for the log of GDP per capita at the start of each period, measures for human resources (life expectancy and fertility rate), investments as a percentage of GDP, a measure of openness (exports and imports over GDP), inflation, government expenditure and an index of democracy as defined in the Polity IV dataset (ranging from -10 to 10). We have also included a dummy for a banking and a currency crisis as debt crises, currency crises and banking crises are often correlated. We lag all the control variables by one year. ${ }^{10}$ The list of countries is presented in appendix A, the list and description of the variables is provided in appendix B, while the descriptive statistics are presented in appendix D.

\footnotetext{
${ }^{10}$ We also tried to include some of the ICRG indicators but missing data reduced the sample substantially, so we do not report the results below. We have also included some measures for "education" (see for example Barro and Lee 2010) but they were never significant. Different specifications are available upon request.
} 


\section{Empirical results}

The results of the model of equation (1) are presented in Table 1. In column 1, 2 and 3 we report only the coefficients of the haircut, of the default and of both variables together, respectively. Column 4 reports the coefficients of the haircut in the year of the default and one year before and after the default episode. Column 5 reports the coefficients of the default in the year of the default and one year before and after the default, while column 6 reports all these coefficients together. Column 7 adds the coefficients of the default two and three years after the default episode to the specification shown in column 4, while column 8 adds the coefficients of the haircut two and three years after the default episode to the specification of column 5. Finally column 9 reports the full model. While all these results are reported for comparison, we largely base our discussion on the full model.

As can be seen, all our control variables have the expected impact on growth. Growth rates significantly increases with lower initial GDP, higher investment and greater openness, while it decreases with higher public expenditure, higher inflation and after the occurrence of a banking crisis. The coefficients of a currency crisis, life expectancy, fertility and democracy are not significant, which is probably due to their (annual) frequency.

In column 1 we can observe that the impact of a debt default on growth is negative and highly significant. In particular growth decreases by about 2.3 percentage points. Column 2 shows that haircuts have also a negative and highly significant (but much lower) impact on growth. An increase of one standard deviation in the haircut decreases growth by about 0.37 per cent. However, when these two variables are included together (in column 3), they both keep their negative sign but only the default dummy remains significant.

Similar results are obtained when we first include both the lagged and the lead values of a default (in column 4), and then both the lagged and the lead values of the haircut (in column 5). They both have a negative and significant impact on growth the year of the default and also two years after the default (for the haircut). ${ }^{11}$ When all these variables are included together, in column 6 , the coefficient of the (contemporaneous) default remains negative and significant (even if smaller in magnitude), while the coefficient of an haircut becomes significant only one year after the default.

More interesting results are obtained when we control for the impact of default and haircut from one year before the default up to three years after the default episode (see columns 7 and 8). In particular, column 8 shows that the coefficient of an haircut is still significant in the third year after the default, when it shows a positive sign, which is maintained in the full specification of column 9. This result suggests that countries which have experienced more severe default, but benefitted by greater haircuts, eventually experience an increase in their rates of growth in the third year after the default episode.

\footnotetext{
${ }^{11}$ Levy Yeyati and Panizza (2011) obtain similar results in Table 2 of their paper. More specifically, they report a negative and significant coefficient for the lagged and the contemporaneous value of a default.
} 
The coefficient of the default dummy remains instead significant only in the year in which the default occurs.

In conclusion, our results are consistent with previous results in the literature as far as the (short-term) effects of a debt default on growth are concerned. More importantly, we show that the simple use of a variable controlling for the severity of the default episode allows us to detect a more lasting (and eventually positive) effect of the debt default on growth. Our results are similar to those of Cruces and Trebesch (2013a) who are also able to detect a long lasting effect of a default on the ability to re-access credit markets by controlling for the intensity of the default through the haircut's size.

\section{TABLE 1 HERE}

Finally, we replicated the analysis by using a GLS estimator correcting for crosssectional heteroskedasticity across countries and autocorrelation within panels. The results are presented in appendix E and confirm the results obtained trough OLS. ${ }^{12}$

\section{Conclusions}

This paper studies the impact of debt default on growth taking the depth of the debt restructuring into account. More specifically, the creditors' losses (or haircuts) are used as proxies of the severity of the default episode. Analyzing 89 defaults in 72 countries over the period 1979-2005, we find that defaults have a negative and significant impact on short-term output growth. Controlling for the intensity of the default through the haircut's size, however, we find that more severe defaults are correlated with a further contraction in output one year after the default and with a positive increase in output three years after the default. Therefore, the use of a variable which is taken as a proxy of the severity of the default episode allows us to detect a more lasting (and eventually positive) effect of default on growth.

More severe haircuts then seem, at the same time, more costly in terms of growth in the short-term but also more beneficial in the medium-term. In other words, there should exist an optimal size of the haircut balancing the ex-ante efficiency of a debt restructuring with its efficiency ex-post. Deriving implications concerning the optimal size of the haircut, however, is not so obvious. For example, lowering too much the costs of renegotiations could, at least in principle, make a default too easy by increasing the spread requested ex ante by the investors.

We should finally emphasize that the direction of causality in the relationship between sovereign defaults and growth raises some questions and thus a robust association between debt defaults and low growth can only be indicative of a correlation between the two

\footnotetext{
${ }^{12}$ In particular, the results of the full specification in column 9 of appendix E are very similar (but smaller in magnitude) to those presented in column 9 of Table 1.
} 
variables. Lower growth might not be the consequence of a default per se but of other factors affecting debt sustainability as well. Thus, both the determinants and the effects of a debt restructuring should be more carefully investigated. For example, additional data on haircuts (such those recently made available by Cruces and Trebesch 2013b) would allow us to use more precise information concerning the haircut of every single restructuring episode rather than after a default episode only. We leave this to further research.

\section{References}

[1] Barro R. J. and X. Sala-i-Martin. 2004. Economic Growth (Second Edition ed.). The MIT Press.

[2] Barro R. and J.W. Lee. 2010. A New Data Set of Educational Attainment in the World, 1950-2010. NBER Working Paper No. 15902.

[3] Beers, D.T. and J.C. Chambers. 2006. Default Study: Sovereign Defaults At 26-Year Low, To Show Little Change In 2007. Standard \& Poor's Credit Week, September 18.

[4] Benjamin, D. and M.L. Wright. 2009. Recovery Before Redemption: a Theory of Delays in Sovereign Debt Renegotiations. CAMA Working Paper Series.

[5] Borensztein E. and U. Panizza. 2009. The costs of sovereign default. IMF Staff Papers $56(4), 683-741$

[6] Borensztein E., and U. Panizza. 2010. Do Sovereign Defaults Hurt Exporters? Open Economic Review 21(3), 339-412.

[7] Bulow J. and K. Rogoff. 1989. Sovereign Debt: Is to Forgive to Forget? American Economic Review 79(1), 43-50.

[8] Center for Systemic Peace. 2012. Polity IV Annual Time-Series 1800-2010.

[9] Cline, William, 1995. International Debt Reexamined. Washington, DC: Institute for International Economics

[10] Cole H.L., Dow J. and W.B. English. 1995. Default, Settlement and Signalling: Lending Resumption in a Reputational Model of Sovereign Debt. International Economic Review, 36, 365-384.

[11] Cruces J. J. and C. Trebesch. 2013a. Sovereign Defaults: The Price of Haircuts. American Economic Journal: Macroeconomics 5, 85-117

[12] Cruces J. J. and C. Trebesch. 2013b. Sovereign Defaults: The Price of Haircuts: Dataset. American Economic Journal: Macroeconomics. http://dx.doi.org/10.1257/mac.5.3.85. 
[13] De Paoli B., Hoggarth G., and V. Saporta. 2006. Costs of Sovereign Default. Financial Stability Paper No. 1.

[14] De Paoli B., Hoggarth G. and V. Saporta. 2009. Output costs of sovereign crises: some empirical estimates. Bank of England Working Paper No. 362.

[15] Eaton J J. and M. Gersovitz. 1981. Debt with Potential Repudation: Theoretical and Empirical Analysis. Review of Economic Studies 48(2), 289-309.

[16] English W.B. 1996. Understanding the Costs of Sovereign Default: American State Debts in the 1840's. American Economic Review 86 (1), pp. 259-275.

[17] Furceri F. and A. Zdzienicka 2012. How costly are debt crises? Journal of International Money and Finance 31, 726-742

[18] Gelos G., Sahay R. and G. Sandleris. 2011. Sovereign Borrowing by developing countries: what determines market Access? Journal of International Economics 83 (2), $243-254$.

[19] Levy Yeyati E. and U. Panizza. 2011. The Elusive Costs of Sovereign Defaults. Journal of Development Economics 94, 95-105.

[20] Lindert P. and P. Morton. 1989. How Sovereign Debt has Worked. In Sachs J. (ed.) Developing Country Debt and Economic Performance. The International Financial System, Vol. 1. The University of Chicago Press.

[21] Marshall M.G. and K. Jaggers. 2009. Polity IV Project: Political Regime Characteristics and Transitions, 1800-2007. University of Maryland.

[22] Ozler S. 1993. Have commercial banks ignored history? American Economic Review 89 (3), 473-500.

[23] Panizza U., Sturzenegger F. and J. Zettelmeyer. 2009. The Economics and Law of Sovereign Debt and Default. Journal of Economic Literature 47(3), 1-47.

[24] Reinhart C. M. and K.S. Rogoff. 2009. This Time is Different: Eight Centuries of Financial Follies. Princeton University Press.

[25] Rose A. K. 2005. One Reason Countries Pay Their Debts: Renegotiation and International Trade. Journal of Development Economics 77, 189-206.

[26] Sturzenegger F. 2004. Tools for the Anlysis of debt problems. Journal of Reconstructing Finance 1(1), 1 - 23.

[27] Sturzenegger F. and J. Zettelmeyer. 2008. Haircuts: Estimating Investor Losses in Sovereign Debt Restructurings, 1998-2005. Journal of International Money and Finance $27,780-805$. 
[28] Tomz M. and M. Wright. 2007. Do countries default in bad times? Journal of the European Economic Association 5 (2), 352-360.

[29] World Bank. 2011. World Development Indicators.

[30] Wright M. L. 2002. Reputations and Sovereign Debt. Stanford University. Unpublished.

[31] Zettelmeyer J., Trebesch C. and M. Gulati. 2013. The Greek Debt Restructuring: An Autopsy. CESifo Working Paper No. 4333 


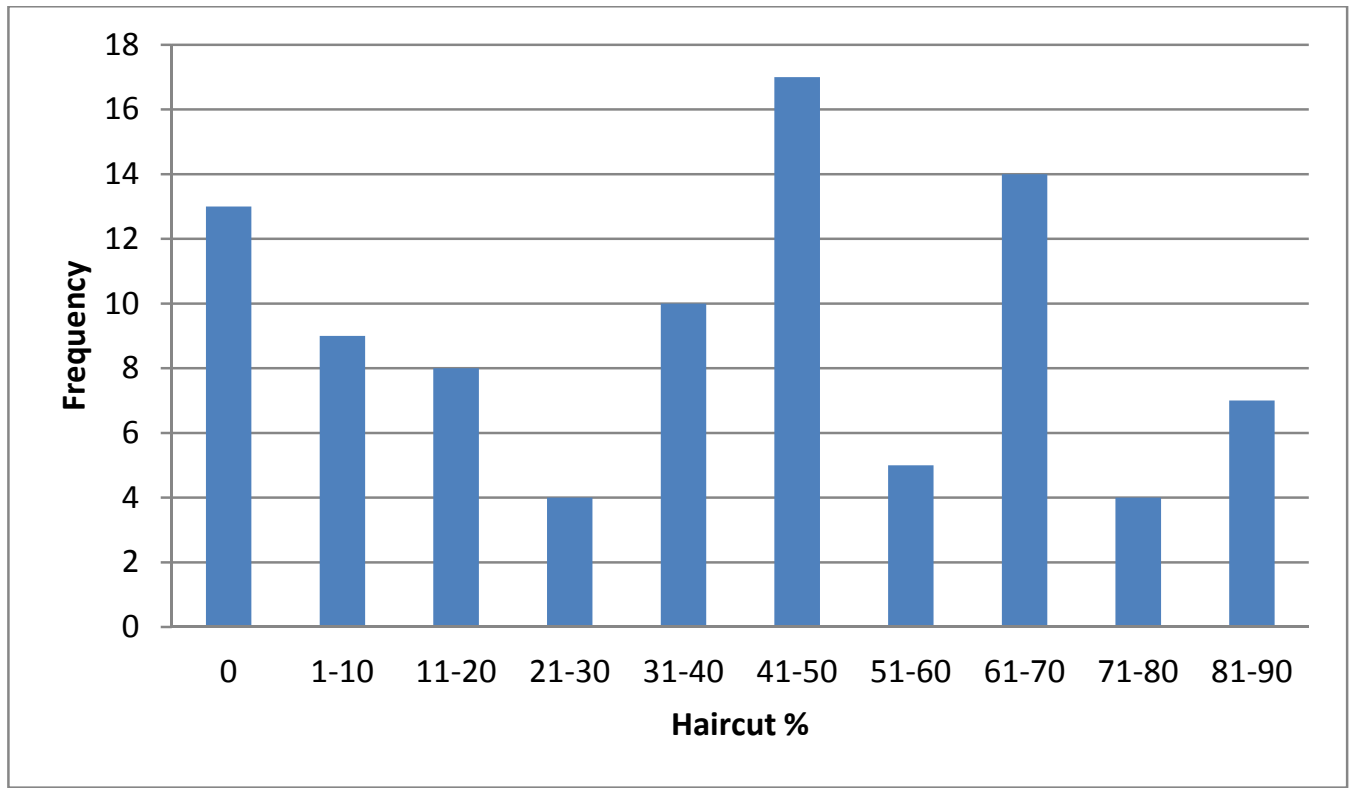

Figure 1: haircut distribution. Source Benjamin e Wright (2009) 
Table 1: default haircuts and growth, 1978-2008, OLS

\begin{tabular}{|c|c|c|c|c|c|c|c|c|c|}
\hline & (1) & $(2)$ & (3) & $(4)$ & (5) & (6) & $(7)$ & (8) & (9) \\
\hline Haircut (-1) & & & & & $\begin{array}{c}-0.003 \\
(-0.236)\end{array}$ & $\begin{array}{c}0.015 \\
(0.744)\end{array}$ & & $\begin{array}{c}-0.001 \\
(-0.064)\end{array}$ & $\begin{array}{c}0.017 \\
(0.834)\end{array}$ \\
\hline Haircut & & $\begin{array}{c}-0.047^{* * *} \\
(-2.957)\end{array}$ & $\begin{array}{c}-0.017 \\
(-0.925)\end{array}$ & & $\begin{array}{c}-0.050^{* * *} \\
(-2.978)\end{array}$ & $\begin{array}{c}-0.020 \\
(-1.019)\end{array}$ & & $\begin{array}{c}-0.047^{* * *} \\
(-2.773)\end{array}$ & $\begin{array}{c}-0.017 \\
(-0.870)\end{array}$ \\
\hline Haircut $(+1)$ & & & & & $\begin{array}{l}-0.039^{* *} \\
(-2.132)\end{array}$ & $\begin{array}{l}-0.049^{*} \\
(-1.952)\end{array}$ & & $\begin{array}{l}-0.036^{* *} \\
(-2.014)\end{array}$ & $\begin{array}{l}-0.047^{*} \\
(-1.893)\end{array}$ \\
\hline Haircut (+2) & & & & & & & & $\begin{array}{c}0.018 \\
(1.010)\end{array}$ & $\begin{array}{c}0.003 \\
(0.130)\end{array}$ \\
\hline Haircut (+3) & & & & & & & & $\begin{array}{l}0.023^{*} \\
(1.724)\end{array}$ & $\begin{array}{l}0.036^{*} \\
(1.891)\end{array}$ \\
\hline Default $(-1)$ & & & & $\begin{array}{c}-0.472 \\
(-0.957)\end{array}$ & & $\begin{array}{c}-1.031 \\
(-1.630)\end{array}$ & $\begin{array}{c}-0.402 \\
(-0.806)\end{array}$ & & $\begin{array}{c}-1.014 \\
(-1.628)\end{array}$ \\
\hline Default & $\begin{array}{c}-2.269^{* * *} \\
(-3.829)\end{array}$ & & $\begin{array}{c}-1.669^{* * *} \\
(-3.214)\end{array}$ & $\begin{array}{c}-2.350^{* * *} \\
(-3.777)\end{array}$ & & $\begin{array}{c}-1.639^{* * *} \\
(-3.012)\end{array}$ & $\begin{array}{l}-2.272^{* * *} \\
(-3.663)\end{array}$ & & $\begin{array}{c}-1.625^{* * *} \\
(-3.105)\end{array}$ \\
\hline Default $(+1)$ & & & & $\begin{array}{c}-1.062 \\
(-1.388)\end{array}$ & & $\begin{array}{c}0.569 \\
(0.613)\end{array}$ & $\begin{array}{c}-0.982 \\
(-1.307)\end{array}$ & & $\begin{array}{c}0.595 \\
(0.653)\end{array}$ \\
\hline Default $(+2)$ & & & & & & & $\begin{array}{c}0.947 \\
(1.413)\end{array}$ & & $\begin{array}{c}0.809 \\
(1.131)\end{array}$ \\
\hline Default $(+3)$ & & & & & & & $\begin{array}{c}0.555 \\
(0.974)\end{array}$ & & $\begin{array}{c}-0.760 \\
(-0.990)\end{array}$ \\
\hline (log) GDPpc (-1) & $\begin{array}{c}-8.231^{* * *} \\
(-5.693)\end{array}$ & $\begin{array}{l}-8.206^{* * *} \\
(-5.744)\end{array}$ & $\begin{array}{c}-8.201^{* * *} \\
(-5.695)\end{array}$ & $\begin{array}{l}-8.161^{* * *} \\
(-5.626)\end{array}$ & $\begin{array}{l}-8.099^{* * *} \\
(-5.722)\end{array}$ & $\begin{array}{c}-8.069^{* * *} \\
(-5.651)\end{array}$ & $\begin{array}{c}-8.134^{* * *} \\
(-5.752)\end{array}$ & $\begin{array}{c}-8.138^{* * *} \\
(-5.838)\end{array}$ & $\begin{array}{c}-8.099^{* * *} \\
(-5.774)\end{array}$ \\
\hline Gov. Expend (-1) & $\begin{array}{l}-0.142^{* *} \\
(-2.249)\end{array}$ & $\begin{array}{l}-0.144^{* *} \\
(-2.300)\end{array}$ & $\begin{array}{l}-0.143^{* *} \\
(-2.268)\end{array}$ & $\begin{array}{l}-0.141^{* *} \\
(-2.237)\end{array}$ & $\begin{array}{l}-0.145^{* *} \\
(-2.327)\end{array}$ & $\begin{array}{l}-0.143^{* *} \\
(-2.290)\end{array}$ & $\begin{array}{l}-0.137^{* *} \\
(-2.182)\end{array}$ & $\begin{array}{l}-0.139^{* *} \\
(-2.228)\end{array}$ & $\begin{array}{l}-0.137^{* *} \\
(-2.195)\end{array}$ \\
\hline Investments (-1) & $\begin{array}{c}0.177^{* * *} \\
(4.066)\end{array}$ & $\begin{array}{c}0.176^{* * *} \\
(4.051)\end{array}$ & $\begin{array}{c}0.176^{* * *} \\
(4.060)\end{array}$ & $\begin{array}{c}0.174^{* * *} \\
(4.029)\end{array}$ & $\begin{array}{c}0.172^{* * *} \\
(3.935)\end{array}$ & $\begin{array}{c}0.173^{* * *} \\
(3.934)\end{array}$ & $\begin{array}{c}0.175^{* * *} \\
(4.013)\end{array}$ & $\begin{array}{c}0.175^{* * *} \\
(3.964)\end{array}$ & $\begin{array}{c}0.175^{* * *} \\
(3.949)\end{array}$ \\
\hline Openness (-1) & $\begin{array}{l}0.023^{*} \\
(1.950)\end{array}$ & $\begin{array}{c}0.023^{*} \\
(1.971)\end{array}$ & $\begin{array}{c}0.023^{*} \\
(1.950)\end{array}$ & $\begin{array}{c}0.023^{*} \\
(1.934)\end{array}$ & $\begin{array}{c}0.023^{*} \\
(1.988)\end{array}$ & $\begin{array}{l}0.022^{*} \\
(1.928)\end{array}$ & $\begin{array}{c}0.022^{*} \\
(1.889)\end{array}$ & $\begin{array}{c}0.023^{*} \\
(1.975)\end{array}$ & $\begin{array}{c}0.022^{*} \\
(1.936)\end{array}$ \\
\hline Inflation (-1) & $\begin{array}{c}-10.991^{* * *} \\
(-4.924)\end{array}$ & $\begin{array}{c}-10.960^{* * *} \\
(-4.964)\end{array}$ & $\begin{array}{c}-10.987^{* * *} \\
(-4.936)\end{array}$ & $\begin{array}{c}-10.972^{* * *} \\
(-4.873)\end{array}$ & $\begin{array}{c}-10.906^{* * *} \\
(-4.924)\end{array}$ & $\begin{array}{c}-10.956^{* * *} \\
(-4.903)\end{array}$ & $\begin{array}{c}-11.006^{* * *} \\
(-4.902)\end{array}$ & $\begin{array}{c}-10.909^{* * *} \\
(-4.916)\end{array}$ & $\begin{array}{c}-10.958^{* * *} \\
(-4.900)\end{array}$ \\
\hline Banking crisis & $\begin{array}{c}-1.555^{* * *} \\
(-3.634)\end{array}$ & $\begin{array}{c}-1.587^{* * *} \\
(-3.732)\end{array}$ & $\begin{array}{c}-1.558^{* * *} \\
(-3.647)\end{array}$ & $\begin{array}{c}-1.519^{* * *} \\
(-3.510)\end{array}$ & $\begin{array}{c}-1.573^{* * *} \\
(-3.630)\end{array}$ & $\begin{array}{c}-1.509^{* * *} \\
(-3.497)\end{array}$ & $\begin{array}{c}-1.531^{* * *} \\
(-3.490)\end{array}$ & $\begin{array}{l}-1.582^{* * *} \\
(-3.605)\end{array}$ & $\begin{array}{c}-1.522^{* * *} \\
(-3.477)\end{array}$ \\
\hline Currency (crisis) & $\begin{array}{c}0.458 \\
(1.173)\end{array}$ & $\begin{array}{c}0.400 \\
(1.016)\end{array}$ & $\begin{array}{c}0.446 \\
(1.140)\end{array}$ & $\begin{array}{c}0.483 \\
(1.230)\end{array}$ & $\begin{array}{c}0.404 \\
(1.011)\end{array}$ & $\begin{array}{c}0.442 \\
(1.113)\end{array}$ & $\begin{array}{c}0.497 \\
(1.265)\end{array}$ & $\begin{array}{c}0.423 \\
(1.051)\end{array}$ & $\begin{array}{c}0.453 \\
(1.131)\end{array}$ \\
\hline$(\log )$ Fertility $(-1)$ & $\begin{array}{c}-1.845 \\
(-1.042)\end{array}$ & $\begin{array}{c}-1.936 \\
(-1.089)\end{array}$ & $\begin{array}{c}-1.881 \\
(-1.064)\end{array}$ & $\begin{array}{c}-1.848 \\
(-1.045)\end{array}$ & $\begin{array}{c}-2.014 \\
(-1.131)\end{array}$ & $\begin{array}{c}-1.938 \\
(-1.096)\end{array}$ & $\begin{array}{c}-1.789 \\
(-1.012)\end{array}$ & $\begin{array}{c}-1.837 \\
(-1.026)\end{array}$ & $\begin{array}{c}-1.759 \\
(-0.987)\end{array}$ \\
\hline$(\log )$ Life Exp (-1) & $\begin{array}{c}2.111 \\
(0.747)\end{array}$ & $\begin{array}{c}2.075 \\
(0.734)\end{array}$ & $\begin{array}{c}2.075 \\
(0.736)\end{array}$ & $\begin{array}{c}1.924 \\
(0.688)\end{array}$ & $\begin{array}{c}1.885 \\
(0.675)\end{array}$ & $\begin{array}{c}1.912 \\
(0.693)\end{array}$ & $\begin{array}{c}2.126 \\
(0.760)\end{array}$ & $\begin{array}{c}2.115 \\
(0.756)\end{array}$ & $\begin{array}{c}2.152 \\
(0.778)\end{array}$ \\
\hline Democracy & $\begin{array}{c}0.024 \\
(0.562)\end{array}$ & $\begin{array}{c}0.021 \\
(0.501)\end{array}$ & $\begin{array}{c}0.023 \\
(0.545)\end{array}$ & $\begin{array}{c}0.022 \\
(0.514)\end{array}$ & $\begin{array}{c}0.019 \\
(0.432)\end{array}$ & $\begin{array}{c}0.022 \\
(0.507)\end{array}$ & $\begin{array}{c}0.023 \\
(0.534)\end{array}$ & $\begin{array}{c}0.016 \\
(0.379)\end{array}$ & $\begin{array}{c}0.019 \\
(0.439)\end{array}$ \\
\hline Costant & $\begin{array}{c}52.355^{* * *} \\
(3.471)\end{array}$ & $\begin{array}{c}52.432^{* * *} \\
(3.483)\end{array}$ & $\begin{array}{c}52.345^{* * *} \\
(3.475)\end{array}$ & $\begin{array}{c}52.689^{* * *} \\
(3.492)\end{array}$ & $\begin{array}{c}52.628^{* * *} \\
(3.524)\end{array}$ & $\begin{array}{c}52.245^{* * *} \\
(3.522)\end{array}$ & $\begin{array}{c}51.564^{* * *} \\
(3.458)\end{array}$ & $\begin{array}{c}51.672^{* * *} \\
(3.484)\end{array}$ & $\begin{array}{c}51.167^{* * *} \\
(3.473)\end{array}$ \\
\hline Observations & 1,514 & 1,514 & 1,514 & 1,514 & 1,514 & 1,514 & 1,514 & 1,514 & 1,514 \\
\hline R-squared & 0.301 & 0.300 & 0.301 & 0.303 & 0.304 & 0.306 & 0.305 & 0.307 & 0.309 \\
\hline Number of id & 64 & 64 & 64 & 64 & 64 & 64 & 64 & 64 & 64 \\
\hline
\end{tabular}

Notes: Robust t-statistics in brackets, ${ }^{* * *} \mathrm{p}<0.01,{ }^{* *} \mathrm{p}<0.05,{ }^{*} \mathrm{p}<0.1$. All regressions include country fixed effects and time dummies. 
Appendix A: list of countries

\begin{tabular}{lll}
\hline \hline Albania & Giordania & Peru \\
Algeria & Guatemala & Polonia \\
Angola & Guinea & Repubblica Centrafricana \\
Argentina & Guinea-Bissau & Romania \\
Bolivia & Guyana & Russia \\
Brasile & Haiti & Ruanda \\
Bulgaria & Honduras & Sao Tome e Principe \\
Burkina Faso & Isole Salomone & Senegal \\
Camerun & Kenya & Seychelles \\
Capo Verde & Macedonia & Sierra Leone \\
Cile & Madagascar & Sud Africa \\
Costa Rica & Mauritania & Sri Lanka \\
Costa d'Avorio & Messico & Tanzania \\
Croazia & Moldavia & Thailandia \\
Colombia & Mongolia & Togo \\
Dominica & Marocco & Trinidad e Tobago \\
Repubblica Dominicana & Mozambico & Uganda \\
Ecuador & Myanmar & Ucraina \\
El Salvador & Nicaragua & Uruguay \\
Etiopia & Niger & Venezuela \\
Filippine & Nigeria & Vietnam \\
Gabon & Pakistan & Yemen \\
Gambia & Panama & Zambia \\
Giamaica & Paraguay & Zimbabwe \\
\hline \hline
\end{tabular}


Appendix B: sources and definition

\begin{tabular}{|c|c|c|c|}
\hline Variable & Definition & Unit & Source \\
\hline \multicolumn{4}{|c|}{ DEPENDENT VARIABLE } \\
\hline GDP growth & Per capita GDP (constant 2000 US\$) & Annual rate of change & WDI (2011) \\
\hline \multicolumn{4}{|c|}{ VARIABLES OF INTEREST } \\
\hline Haircut & $\begin{array}{l}\text { Private creditors haircut are } \\
\text { calculated taking into account only } \\
\text { defaults on sovereign debts owed to } \\
\text { private sector creditors (banks and } \\
\text { bondholders). Measures are based on } \\
\text { the World Bank's estimates of debt } \\
\text { stock reduction, interest and } \\
\text { principal forgiven, and debt } \\
\text { buybacks, as in the Global } \\
\text { Development Finance (GDF), } \\
\text { combined with estimates of the } \\
\text { Institute for International Finance. } \\
\text { Losses in different years were added } \\
\text { together and discounted back to the } \\
\text { time of the default using a } 10 \% \\
\text { discount rate. }\end{array}$ & Percentage of the outstantding debt & Benjamin \& Wright (2009) \\
\hline Default & $\begin{array}{l}\text { Default is defined as in Standard and } \\
\text { Poors, namely if a payment is not } \\
\text { made within any grace period } \\
\text { specified in the contract, or if debts } \\
\text { are rescheduled on terms less } \\
\text { favorable than those specified in the } \\
\text { original debt contract }\end{array}$ & $\begin{array}{l}\text { Dummy equal to } 1 \text { the year of the } \\
\text { default, } 0 \text { otherwise }\end{array}$ & Benjamin \& Wright (2009) \\
\hline
\end{tabular}




\section{CONTROL VARIABLES}

Initial per cap. GDP (log)

Investment

Government consumption

Inflation

Openness

Life fertility $(\log )$

Life exp. $(\log )$

Democracy

Banking crisis

Currency crisis
Log of per capita GDP at the Constant 2000 US \$

WDI (2011)

beginning of the period

Gross fixed capital formation Ratio to GDP

WDI (2011)

General Government

Consumption Expenditure

Inflation, consumer price

Final Ratio to GDP

WDI (2011)

Annual rate of change WDI (2011)

Exports plus Imports of goods and Ratio to GDP

WDI (2011)

services

Fertility rate (birth per woman) Unit WDI (2011)

Log of life expectancy Unit WDI (2011)

Polity2 score taken from the Polity IV Unit (+10 democray, -10 autocracy) Marshall and Jaggers (2009)

dataset

We mark a banking crisis by two Dummy equal 1 in the case of a Reinhart and Rogoff (2009)

types of events: (1) bank runs that banking crisis, 0 otherwise

lead to the closure, merging, or

takeover by the public sector of one

or more financial institutions; (2) if

there are no runs, the closure,

merging, take-over or large-scale

government assistance of an

important financial institution (or group of institutions) that mark the start of a string of similar outcomes for other financial institutions (see Reinhart e Rogoff 2009).

An annual depreciation versus the Dummy equal 1 in the case of a Built by the authors (based on U.S. dollar $15 \%$ or more (see Reinhart currency crisis, 0 otherwise World Bank 2011) and Rogoff 2009) 


\section{Appendix C: data on default and haircuts}

\begin{tabular}{|c|c|c|c|c|c|c|c|}
\hline Paese & $\begin{array}{l}\text { Default } \\
\text { begins }\end{array}$ & $\begin{array}{l}\text { Default } \\
\text { ends }\end{array}$ & Haircut & Paese & $\begin{array}{l}\text { Default } \\
\text { begins }\end{array}$ & $\begin{array}{l}\text { Default } \\
\text { ends }\end{array}$ & Haircut \\
\hline Albania & 1991 & 1995 & 38 & Mozambico & 1983 & 1992 & 57 \\
\hline Algeria & 1991 & 1996 & 0 & Myanmar & 1997 & 2003 & 43 \\
\hline Angola & 1985 & 2004 & 69 & Nicaragua & 1979 & 2003 & 75 \\
\hline Argentina & 1982 & 1993 & 30 & Niger & 1983 & 1991 & 89 \\
\hline Argentina & 2001 & 2005 & 63 & Nigeria & 1982 & 1992 & 70 \\
\hline Bolivia & 1980 & 1993 & 58 & Nigeria & 2002 & 2002 & 8 \\
\hline Brasile & 1983 & 1994 & 21 & Pakistan & 1998 & 1999 & 29 \\
\hline Bulgaria & 1990 & 1994 & 46 & Panama & 1983 & 1996 & 34 \\
\hline Burkina Faso & 1983 & 1996 & 61 & Paraguay & 1986 & 1993 & 62 \\
\hline Camerun & 1985 & 2003 & 61 & Paraguay & 2003 & 2004 & 0 \\
\hline Capo Verde & 1981 & 1996 & 46 & Peru & 1980 & 1980 & 0 \\
\hline Cile & 1983 & 1990 & 46 & Peru & 1983 & 1997 & 29 \\
\hline Colombia & 1985 & 1991 & 2 & Filippine & 1983 & 1992 & 35 \\
\hline Costa Rica & 1983 & 1990 & 43 & Polonia & 1981 & 1994 & 42 \\
\hline Costa d'Avorio & 1983 & 1998 & 52 & Repubblica Dominicana & 1983 & 1994 & 47 \\
\hline Costa d'Avorio & 2000 & 2004 & 41 & Romania & 1981 & 1983 & 9 \\
\hline Croazia & 1992 & 1996 & 0 & Russia & 1991 & 1997 & 32 \\
\hline Dominica & 2003 & 2004 & 0 & Russia & 1998 & 2000 & 32 \\
\hline Ecuador & 1982 & 1995 & 23 & Ruanda & 1995 & 1995 & 0 \\
\hline Ecuador & 1999 & 2000 & 34 & Sao Tome e Principe & 1987 & 1994 & 48 \\
\hline Ecuador & 2000 & 2001 & 0 & Senegal & 1990 & 1990 & 3 \\
\hline El Salvador & 1981 & 1996 & 64 & Senegal & 1992 & 1996 & 10 \\
\hline Etiopia & 1991 & 1999 & 44 & Seychelles & 2000 & 2002 & 12 \\
\hline Gabon & 1986 & 1994 & 42 & Sierra Leone & 1986 & 1995 & 85 \\
\hline Gabon & 1999 & 2004 & 85 & Sierra Leone & 1997 & 1998 & 51 \\
\hline Gambia & 1986 & 1990 & 63 & Isole Salomone & 1996 & 2004 & 90 \\
\hline Giamaica & 1987 & 1993 & 60 & Sud Africa & 1993 & 1993 & 0 \\
\hline Giordania & 1989 & 1993 & 44 & Sri Lanka & 1996 & 1996 & 4 \\
\hline Guatemala & 1989 & 1989 & 14 & Tanzania & 1984 & 2004 & 63 \\
\hline Guinea & 1986 & 1988 & 8 & Thailandia & 1997 & 1998 & 0 \\
\hline Guinea & 1991 & 1998 & 14 & Togo & 1991 & 1997 & 66 \\
\hline Guinea-Bissau & 1983 & 1996 & 70 & Trinidad e Tobago & 1988 & 1989 & 4 \\
\hline Guyana & 1982 & 2004 & 85 & Uganda & 1980 & 1993 & 90 \\
\hline Haiti & 1982 & 1994 & 65 & Ucraina & 1998 & 2000 & 1 \\
\hline Honduras & 1981 & 2004 & 72 & Uruguay & 1990 & 1991 & 16 \\
\hline Repubblica Centrafricana & 1983 & 2004 & 66 & Uruguay & 2003 & 2003 & 0 \\
\hline Kenya & 1994 & 2004 & 85 & Venezuela & 1990 & 1990 & 14 \\
\hline Macedonia & 1992 & 1997 & 60 & Venezuela & 1995 & 1997 & 2 \\
\hline Madagascar & 1981 & 2002 & 68 & Venezuela & 1998 & 1998 & 0 \\
\hline Mauritania & 1992 & 1996 & 48 & Venezuela & 2005 & 2005 & 0 \\
\hline Messico & 1982 & 1990 & 34 & Vietnam & 1985 & 1998 & 58 \\
\hline Moldavia & 1998 & 1998 & 15 & Yemen & 1985 & 2001 & 35 \\
\hline Moldavia & 2002 & 2002 & 42 & Zambia & 1983 & 1994 & 45 \\
\hline Mongolia & 1997 & 2000 & 0 & Zimbabwe & 2000 & 2004 & 19 \\
\hline Marocco & 1986 & 1990 & 42 & & & & \\
\hline
\end{tabular}

Source: Benjamin e Wright (2009) 
Appendix D: descriptive statistics

\begin{tabular}{|c|c|c|c|c|c|}
\hline Variable & Observations & Average & $\begin{array}{l}\text { Standard } \\
\text { deviation }\end{array}$ & Min & Max \\
\hline GDP growth & 1514 & 1.36 & 4.94 & -29.48 & 37.12 \\
\hline$(\log )$ GDPpc & 1514 & 6.92 & 1,05 & 4.63 & 9.30 \\
\hline Gov. Expenditure & 1514 & 14.17 & 5.38 & 2.68 & 64.39 \\
\hline Investment & 1514 & 19.93 & 6.57 & 2.00 & 65.56 \\
\hline Openness & 1514 & 67.79 & 33.11 & 10.83 & 213.33 \\
\hline Inflation & 1514 & 0.13 & 0.16 & -0.13 & 0.99 \\
\hline Banking crisis & 1514 & 0.18 & 0.38 & 0 & 1 \\
\hline Currency crisis & 1514 & 0.26 & 0.44 & 0 & 1 \\
\hline (log) Fertility & 1514 & 1.35 & 0.50 & 0.09 & 2.14 \\
\hline (log) Life Expectancy & 1514 & 4.11 & 0.17 & 3.29 & 4.37 \\
\hline Democracy & 1514 & 2.12 & 6.42 & -10 & 10 \\
\hline Default & 1514 & 0.03 & 0.18 & 0 & 1 \\
\hline Haircut & 1514 & 1.20 & 8.04 & 0 & 89 \\
\hline
\end{tabular}


Appendix E: default haircuts and growth, 1978-2008, GLS

\begin{tabular}{|c|c|c|c|c|c|c|c|c|c|}
\hline & $(1)$ & $(2)$ & (3) & $(4)$ & (5) & (6) & (7) & (8) & (9) \\
\hline Haircut (-1) & & & & & $\begin{array}{c}-0.005 \\
(-0.534)\end{array}$ & $\begin{array}{c}0.012 \\
(0.796)\end{array}$ & & $\begin{array}{c}-0.003 \\
(-0.316)\end{array}$ & $\begin{array}{c}0.015 \\
(0.950)\end{array}$ \\
\hline Haircut & & $\begin{array}{l}-0.021^{* *} \\
(-2.161)\end{array}$ & $\begin{array}{c}-0.002 \\
(-0.137)\end{array}$ & & $\begin{array}{c}-0.029^{* * *} \\
(-2.827)\end{array}$ & $\begin{array}{c}-0.008 \\
(-0.531)\end{array}$ & & $\begin{array}{l}-0.027^{* *} \\
(-2.566)\end{array}$ & $\begin{array}{c}-0.007 \\
(-0.453)\end{array}$ \\
\hline Haircut $(+1)$ & & & & & $\begin{array}{c}-0.029^{* * *} \\
(-2.864)\end{array}$ & $\begin{array}{l}-0.032^{* *} \\
(-2.189)\end{array}$ & & $\begin{array}{l}-0.025^{* *} \\
(-2.312)\end{array}$ & $\begin{array}{l}-0.030^{*} \\
(-1.931)\end{array}$ \\
\hline Haircut (+2) & & & & & & & & $\begin{array}{c}0.015 \\
(1.440)\end{array}$ & $\begin{array}{c}0.010 \\
(0.651)\end{array}$ \\
\hline Haircut (+3) & & & & & & & & $\begin{array}{c}0.014 \\
(1.512)\end{array}$ & $\begin{array}{l}0.023^{*} \\
(1.671)\end{array}$ \\
\hline Default (-1) & & & & $\begin{array}{c}-0.599 \\
(-1.391)\end{array}$ & & $\begin{array}{c}-1.018 \\
(-1.556)\end{array}$ & $\begin{array}{c}-0.536 \\
(-1.239)\end{array}$ & & $\begin{array}{c}-1.029 \\
(-1.578)\end{array}$ \\
\hline Default & $\begin{array}{c}-1.124^{* * *} \\
(-2.706)\end{array}$ & & $\begin{array}{l}-1.063^{*} \\
(-1.675)\end{array}$ & $\begin{array}{c}-1.433^{* * *} \\
(-3.251)\end{array}$ & & $\begin{array}{l}-1.150^{*} \\
(-1.722)\end{array}$ & $\begin{array}{c}-1.360^{* * *} \\
(-3.060)\end{array}$ & & $\begin{array}{l}-1.098^{*} \\
(-1.648)\end{array}$ \\
\hline Default $(+1)$ & & & & $\begin{array}{l}-0.766^{*} \\
(-1.849)\end{array}$ & & $\begin{array}{c}0.226 \\
(0.374)\end{array}$ & $\begin{array}{c}-0.574 \\
(-1.332)\end{array}$ & & $\begin{array}{c}0.340 \\
(0.544)\end{array}$ \\
\hline Default (+2) & & & & & & & $\begin{array}{c}0.635 \\
(1.486)\end{array}$ & & $\begin{array}{c}0.279 \\
(0.449)\end{array}$ \\
\hline Default $(+3)$ & & & & & & & $\begin{array}{c}0.172 \\
(0.432)\end{array}$ & & $\begin{array}{c}-0.546 \\
(-0.918)\end{array}$ \\
\hline (log) GDPpc (-1) & $\begin{array}{l}-8.596^{* * *} \\
(-10.481)\end{array}$ & $\begin{array}{l}-8.615^{* * *} \\
(-10.503)\end{array}$ & $\begin{array}{l}-8.582^{* * *} \\
(-10.471)\end{array}$ & $\begin{array}{l}-8.521^{* * *} \\
(-10.337)\end{array}$ & $\begin{array}{l}-8.603^{* * *} \\
(-10.393)\end{array}$ & $\begin{array}{l}-8.526^{* * *} \\
(-10.297)\end{array}$ & $\begin{array}{l}-8.513^{* * *} \\
(-10.362)\end{array}$ & $\begin{array}{l}-8.668^{* * *} \\
(-10.487)\end{array}$ & $\begin{array}{l}-8.578^{* * *} \\
(-10.369)\end{array}$ \\
\hline Gov. Expend (-1) & $\begin{array}{l}-0.119^{* * *} \\
(-4.080)\end{array}$ & $\begin{array}{c}-0.120^{* * *} \\
(-4.121)\end{array}$ & $\begin{array}{c}-0.119^{* * *} \\
(-4.083)\end{array}$ & $\begin{array}{c}-0.118^{* * *} \\
(-4.037)\end{array}$ & $\begin{array}{c}-0.118^{* * *} \\
(-4.041)\end{array}$ & $\begin{array}{l}-0.117^{* * *} \\
(-4.008)\end{array}$ & $\begin{array}{c}-0.117^{* * *} \\
(-3.986)\end{array}$ & $\begin{array}{c}-0.115^{* * *} \\
(-3.930)\end{array}$ & $\begin{array}{c}-0.114^{* * *} \\
(-3.890)\end{array}$ \\
\hline Investments $(-1)$ & $\begin{array}{c}0.191^{* * *} \\
(7.949)\end{array}$ & $\begin{array}{c}0.192^{* * *} \\
(7.986)\end{array}$ & $\begin{array}{c}0.191^{* * *} \\
(7.957)\end{array}$ & $\begin{array}{c}0.191^{* * *} \\
(7.921)\end{array}$ & $\begin{array}{c}0.192^{* * *} \\
(7.946)\end{array}$ & $\begin{array}{c}0.191^{* * *} \\
(7.896)\end{array}$ & $\begin{array}{c}0.192^{* * *} \\
(7.964)\end{array}$ & $\begin{array}{c}0.195^{* * *} \\
(8.061)\end{array}$ & $\begin{array}{c}0.193^{* * *} \\
(7.962)\end{array}$ \\
\hline Openness (-1) & $\begin{array}{c}0.013^{*} \\
(1.865)\end{array}$ & $\begin{array}{c}0.013^{*} \\
(1.855)\end{array}$ & $\begin{array}{c}0.013^{*} \\
(1.856)\end{array}$ & $\begin{array}{c}0.013^{*} \\
(1.788)\end{array}$ & $\begin{array}{c}0.013^{*} \\
(1.865)\end{array}$ & $\begin{array}{l}0.013^{*} \\
(1.753)\end{array}$ & $\begin{array}{l}0.013^{*} \\
(1.749)\end{array}$ & $\begin{array}{l}0.013^{*} \\
(1.784)\end{array}$ & $\begin{array}{c}0.012^{*} \\
(1.701)\end{array}$ \\
\hline Inflation (-1) & $\begin{array}{l}-9.054^{* * *} \\
(-10.830)\end{array}$ & $\begin{array}{l}-9.048^{* * *} \\
(-10.804)\end{array}$ & $\begin{array}{l}-9.050^{* * *} \\
(-10.824)\end{array}$ & $\begin{array}{l}-8.984^{* * *} \\
(-10.727)\end{array}$ & $\begin{array}{l}-9.012^{* * *} \\
(-10.698)\end{array}$ & $\begin{array}{l}-9.016^{* * *} \\
(-10.723)\end{array}$ & $\begin{array}{l}-9.048^{* * *} \\
(-10.753)\end{array}$ & $\begin{array}{l}-9.033^{* * *} \\
(-10.709)\end{array}$ & $\begin{array}{l}-9.045^{* * *} \\
(-10.735)\end{array}$ \\
\hline Banking crisis & $\begin{array}{c}-1.025^{* * *} \\
(-4.502)\end{array}$ & $\begin{array}{c}-1.035^{* * *} \\
(-4.537)\end{array}$ & $\begin{array}{c}-1.027^{* * *} \\
(-4.505)\end{array}$ & $\begin{array}{c}-0.995^{* * *} \\
(-4.344)\end{array}$ & $\begin{array}{c}-1.027^{* * *} \\
(-4.483)\end{array}$ & $\begin{array}{c}-0.980^{* * *} \\
(-4.269)\end{array}$ & $\begin{array}{c}-1.020^{* * *} \\
(-4.436)\end{array}$ & $\begin{array}{c}-1.049^{* * *} \\
(-4.555)\end{array}$ & $\begin{array}{c}-1.017^{* * *} \\
(-4.391)\end{array}$ \\
\hline Currency crisis & $\begin{array}{c}0.030 \\
(0.137)\end{array}$ & $\begin{array}{c}0.008 \\
(0.035)\end{array}$ & $\begin{array}{c}0.030 \\
(0.133)\end{array}$ & $\begin{array}{c}0.032 \\
(0.142)\end{array}$ & $\begin{array}{c}-0.008 \\
(-0.035)\end{array}$ & $\begin{array}{c}0.009 \\
(0.043)\end{array}$ & $\begin{array}{c}0.047 \\
(0.209)\end{array}$ & $\begin{array}{c}0.016 \\
(0.070)\end{array}$ & $\begin{array}{c}0.031 \\
(0.140)\end{array}$ \\
\hline (log) Fertility $(-1)$ & $\begin{array}{c}-0.729 \\
(-0.602)\end{array}$ & $\begin{array}{c}-0.728 \\
(-0.602)\end{array}$ & $\begin{array}{c}-0.730 \\
(-0.604)\end{array}$ & $\begin{array}{c}-0.854 \\
(-0.699)\end{array}$ & $\begin{array}{c}-0.848 \\
(-0.699)\end{array}$ & $\begin{array}{c}-0.797 \\
(-0.660)\end{array}$ & $\begin{array}{c}-0.771 \\
(-0.628)\end{array}$ & $\begin{array}{c}-0.624 \\
(-0.515)\end{array}$ & $\begin{array}{c}-0.542 \\
(-0.450)\end{array}$ \\
\hline$(\log )$ Life Exp (-1) & $\begin{array}{c}1.921 \\
(0.976)\end{array}$ & $\begin{array}{c}1.633 \\
(0.830)\end{array}$ & $\begin{array}{c}1.839 \\
(0.935)\end{array}$ & $\begin{array}{c}1.830 \\
(0.920)\end{array}$ & $\begin{array}{c}1.207 \\
(0.606)\end{array}$ & $\begin{array}{c}1.378 \\
(0.694)\end{array}$ & $\begin{array}{c}1.896 \\
(0.952)\end{array}$ & $\begin{array}{c}1.153 \\
(0.577)\end{array}$ & $\begin{array}{c}1.258 \\
(0.627)\end{array}$ \\
\hline Democracy & $\begin{array}{c}0.024 \\
(0.929)\end{array}$ & $\begin{array}{c}0.024 \\
(0.923)\end{array}$ & $\begin{array}{c}0.025 \\
(0.939)\end{array}$ & $\begin{array}{c}0.020 \\
(0.755)\end{array}$ & $\begin{array}{c}0.017 \\
(0.646)\end{array}$ & $\begin{array}{c}0.020 \\
(0.745)\end{array}$ & $\begin{array}{c}0.022 \\
(0.855)\end{array}$ & $\begin{array}{c}0.017 \\
(0.657)\end{array}$ & $\begin{array}{c}0.019 \\
(0.729)\end{array}$ \\
\hline Costant & $\begin{array}{c}43.338^{* * *} \\
(4.996)\end{array}$ & $\begin{array}{c}44.555^{* * *} \\
(5.148)\end{array}$ & $\begin{array}{c}43.578^{* * *} \\
(5.026)\end{array}$ & $\begin{array}{c}71.425^{* * *} \\
(6.519)\end{array}$ & $\begin{array}{c}46.338^{* * *} \\
(5.307)\end{array}$ & $\begin{array}{c}45.196^{* * *} \\
(5.182)\end{array}$ & $\begin{array}{c}43.051^{* * *} \\
(4.917)\end{array}$ & $\begin{array}{c}46.476^{* * *} \\
(5.304)\end{array}$ & $\begin{array}{c}45.477^{* * *} \\
(5.170)\end{array}$ \\
\hline Observations & 1,514 & 1,514 & 1,514 & 1,514 & 1,514 & 1,514 & 1,514 & 1,514 & 1,514 \\
\hline Number of id & 64 & 64 & 64 & 64 & 64 & 64 & 64 & 64 & 64 \\
\hline
\end{tabular}

Notes: Robust z-statistics in brackets, ${ }^{* *} \mathrm{p}<0.01,{ }^{* *} \mathrm{p}<0.05,{ }^{*} \mathrm{p}<0.1$. All regressions include country fixed effects and time dummies. 